\title{
Endless cold: a seasonal reconstruction of temperature and precipitation in the Burgundian Low Countries during the 15th century based on documentary evidence
}

\author{
C. Camenisch ${ }^{1,2}$ \\ ${ }^{1}$ Oeschger Centre for Climate Change Research, University of Bern, 3012 Bern, Switzerland \\ ${ }^{2}$ Institute of History, Department of Economic, Social and Environmental History (WSU), \\ University of Bern, Länggassstrasse 49, 3012 Bern, Switzerland \\ Correspondence to: C. Camenisch (chantal.camenisch@hist.unibe.ch)
}

Received: 29 January 2015 - Published in Clim. Past Discuss.: 17 March 2015

Revised: 8 June 2015 - Accepted: 22 July 2015 - Published: 20 August 2015

\begin{abstract}
This paper applies the methods of historical climatology to present a climate reconstruction for the area of the Burgundian Low Countries during the 15th century. The results are based on documentary evidence that has been handled very carefully, especially with regard to the distinction between contemporary and non-contemporary sources. Approximately 3000 written records derived from about 100 different sources were examined and converted into seasonal seven-degree indices for temperature and precipitation. For the Late Middle Ages only a few climate reconstructions exist. There are even fewer reconstructions which include spring and autumn temperature or any precipitation information at all. This paper therefore constitutes a useful contribution to the understanding of climate and weather conditions in the less well researched but highly interesting 15 th century. The extremely cold winter temperatures during the 1430s and an extremely cold winter in 1407/1408 are striking. Moreover, no other year in this century was as hot and dry as 1473 . At the beginning and the end of the 1480s and at the beginning of the 1490s summers were considerably wetter than average.
\end{abstract}

\section{Introduction}

Le Roy Ladurie, one of the pioneers of historical climatology, stated the necessity for a quantitative, continuous and homogeneous series in order to reconstruct climate on the basis of historical documents for the time prior to instrumental records (1972). A true treasure of rich narrative texts, including a variety of weather-related information, can be found in documentary sources produced in the Late Middle Ages (AD 1300-1500). This information consists of direct data (descriptions of temperatures and precipitation) and/or indirect data (climate proxies - phenomena which are related to climate such as the freezing of water bodies or plant phenology). Nonetheless, they are far from being continuous or homogeneous. Moreover, they are not quantitative (Pfister et al., 2009).

As this paper demonstrates, there are methods that facilitate the transformation of this varied information into a reliable climate reconstruction based on quantitative series. The presented paper aims to give an overview of weather conditions during the 15th century in the Burgundian Low Countries and surrounding areas at seasonal resolution with separately reconstructed temperature and precipitation. Leading questions are as follows: (1) what were the characteristics of these weather conditions? (2) what are the advantages of using documentary data and what are the limits of these sources? Selected examples give deeper insight into the characteristics of the sources and the applied methods in order to analyse them and convert them into homogeneous temperature and precipitation index series. The climate reconstruction not only provides an overview of the prevailing weather conditions of the whole century but presents detailed results. Since the source density in most cases is high enough, it is possible to detect not only anomalies but also less extreme weather conditions. This is unusual because most reconstructions based on this type of data focus on extreme weather 
events. Moreover, many climate reconstructions are limited to temperature. As the inclusion of precipitation in reconstructions is crucial in order to obtain a more complete picture of past climates, this is a substantial gain in knowledge (Pfister, 2014). The inclusion of normal weather conditions (apart from extreme events) and precipitation is a precondition for a comparison of climate and weather conditions with human society. Such a comparison is a further aim of historical climatology and will be realised in future research.

The use of documentary evidence for examining past climate has a long tradition. Many catalogues with compilations of weather-related records exist (e.g. Hennig, 1904; Weikinn, 1958; Britton, 1937). These catalogues do not contain any critical source assessment and contain mistakes in dating. Reconstructions on the basis of such compilations repeat the dating errors. Some such catalogues cover the area of the Low Countries during the Late Middle Ages (e.g. Easton, 1928; Vanderlinden, 1924).

In 1987, Alexandre established a benchmark for the reconstruction of medieval climate using documentary sources. Apart from analysing sources throughout continental Europe, the author defined the necessity of a critical source assessment in order to improve the quality of such examinations. Buisman (1995, 1996, 1998, 2000, 2006, 2015) collected an enormous number of documentary sources concerning the climate of the Low Countries. By 2015, six volumes with Dutch translations of weather-relevant records had appeared, covering the period from 1000 to 1800 , and another three volumes are in preparation.

For the present analysis, documentary information was transformed into climate indices. Early examples of the method were published by Lamb $(1977,1982)$. The climate indices were developed and improved by Pfister $(1984,1999)$ and Brázdil and Kotyza (1995) and are a proven way to analyse sources (e.g. Alexandre, 1987; Schwarz-Zanetti, 1998; Dobrovolný et al., 2010, 2014; Brázdil et al., 2013).

Van Engelen used the Buisman (1995, 1996, 1998, 2000) compilation as a basis for climate indices (Shabalova and van Engelen, 2003; van Engelen et al., 2001). The ambitious goal of this Dutch reconstruction was to provide long series with (almost) no gaps. Van Engelen fulfilled this promise by choosing a nine-degree scale for the temperature indices and a five-degree scale for the precipitation indices. The temperature reconstruction is comprised of a winter index (NDJFM) and a summer index (MJJAS).

The aim of the present paper is different. First of all, indices with a higher resolution were necessary because a comparison with economic development is intended, and for that purpose reconstruction at least on the seasonal scale is indispensable (Camenisch, 2015; Pfister, 2014). Furthermore, it was mandatory to read the original texts since it is not possible to produce a reliable reconstruction with summarised and translated excerpts of very diverse sources. The highquality source compilations of Alexandre (1987) and Buisman $(1995,1996,1998,2000,2006,2015)$ were consulted as well. Further important contributions on the medieval climate in the Low Countries were published by, e.g. Gottschalk (1975) and de Kraker $(2005,2013)$. In addition there are useful climate reconstructions focused on regions in the neighbourhood of the Low Countries such as Germany (Glaser, 2013), Switzerland (Schwarz-Zanetti, 1998) France (Le Roy Ladurie, 2004), the current region of Lorraine (Litzenburger, 2015) and Ireland and Britain (Kington, 2010) that are based either on similar source types or on similar methods.

Section 2 gives a short overview of the geographical scope of the research. In the Sect. 3 the data which form the basis of this reconstruction are presented and discussed. Some source examples complete this section. Section 4 is dedicated to the methods. Section 5 covers reconstructions and Sect. 6 provides a summary before Sect. 7 concludes.

\section{Scope}

The 15th century forms part of the Little Ice Age and contains a number of highly interesting weather patterns and phenomena that warrant closer examination (Aberth, 2013; Brooke, 2014; Hoffmann, 2014). Moreover, this period is not as well researched as it should be as the Alexandre (1987) reconstruction ends in 1425 and other reconstructions begin only after 1500 (e.g. Pfister, 1999).

The methods used in this paper require a sufficient number of data. For this reason the Burgundian Low Countries have been chosen as the geographical setting. During the end of the 14th and through the course of the 15th century several parts of present-day Belgium, the Netherlands, Luxembourg and northern France fell under the rule or at least into the sphere of influence of a cadet branch of the French royal dynasty (see Fig. 1). This house of Burgundy reigned for almost 100 years over the Burgundian Low Countries before the male line went extinct (Calmette, 1996; Schnerb, 1999). In 1477 when the last of the dukes of Burgundy, Charles the Bold, died, his territory extended from the English Channel in the west to the Ardennes in the east, and in the north from the West Frisian Islands to the Duchy of Luxembourg in the south (Blockmans and Prevenier, 1999; Prevenier and Blockmans, 1986).

The topography of the inshore area is particularly flat and the land largely lies below sea level. Only in the east do the hills of the Ardennes contrast with the otherwise flat topography. Weathering processes triggered by storm surges, ocean waves and currents have formed and continue to form the shoreline today (de Voogd, 2003; Reuss, 2006; Buisman, 2011). Large rivers such as the Rhine, Scheldt, Meuse and IJssel cut through the plains before flowing into the North Sea. The area belongs to the most fertile agricultural landscapes of Europe thanks to the soil conditions, cultivation of land and soil improvement. Consequently, a remarkable level of agricultural productivity and the proximity to waterways the fastest and most efficient transportation routes of the time 


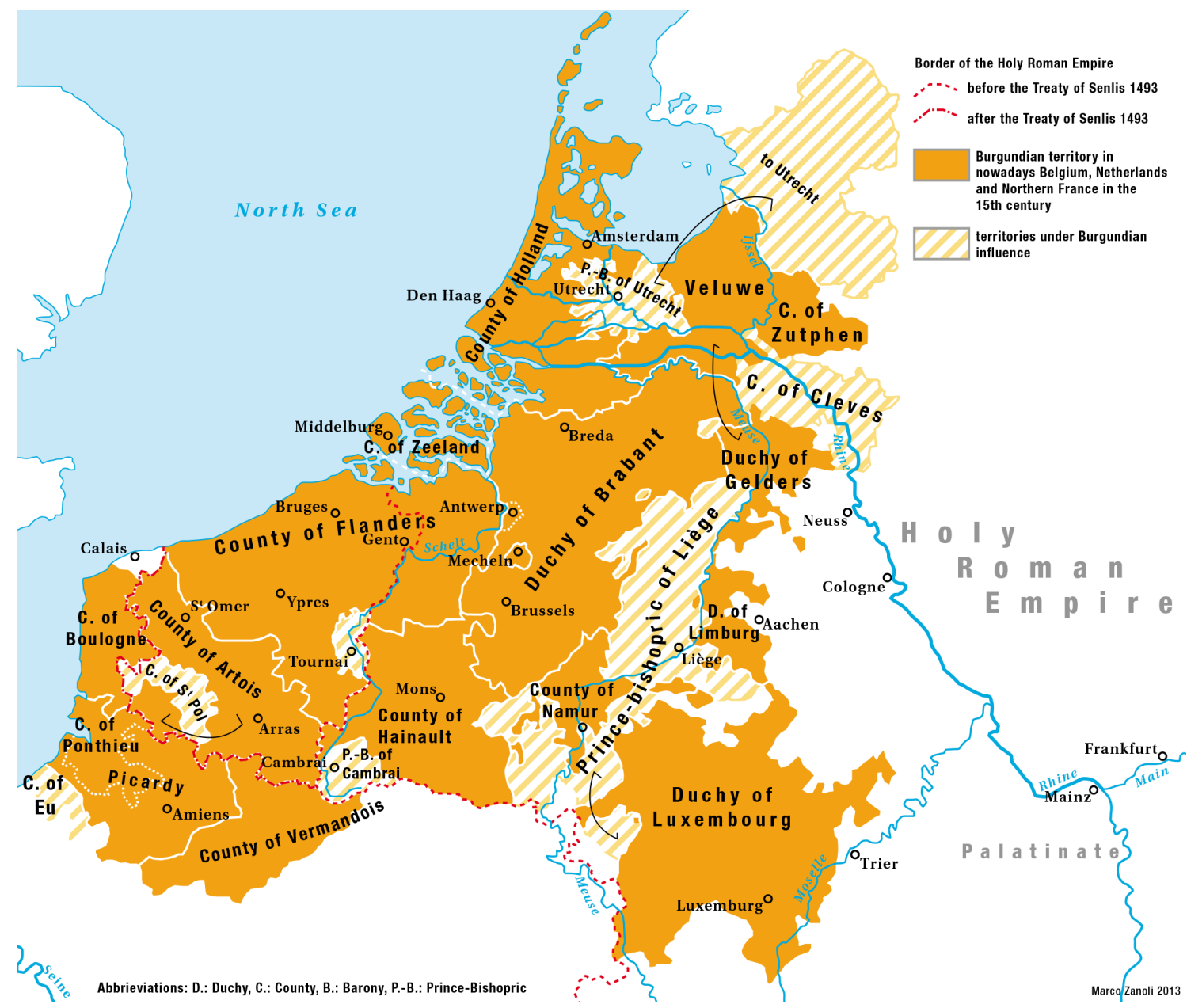

Figure 1. The Burgundian Low Countries (map from Marco Zanoli).

- created an extraordinarily dense population (Erbe, 1993; Allen, 2000; Prevenier and Blockmans, 1986). The urbanisation level of the Burgundian Low Countries was exceptional. Extraordinarily populous cities were situated in Flanders, Artois, Brabant and Holland (van Bavel, 2010). This prosperous area was famous for its artistic production. Furthermore, a rich historiography and accurate and elaborate records exist which form the basis of this research.

\section{Sources}

\subsection{Classification}

In order to reconstruct temperature and precipitation several methods based on a variety of data are required. Besides the rich natural archives consisting of organic proxies (such as tree rings) and non-organic proxies (including ice cores, varves and terrestrial sediments), man-made archives are also useful. Those archives contain documentary data and are the basis of climate reconstructions derived from historical climatology (Brázdil et al., 2005; Pfister, 1999; Pfister et al.,
1999). Documentary evidence allows precise dating with a very high resolution. There are annual, seasonal, monthly or even daily observations depending on the type of information. Early instrumental measurement did not begin until the 17th century and is therefore not available for the Late Middle Ages (Behringer, 2010). Instead, other direct and indirect data provide information on climate. Direct data are descriptive records on weather spells, climatic anomalies or weather-induced disasters. Indirect data or proxy data are comprised of records of both organic and non-organic evidence that allow inferences regarding temperature and precipitation such as plant phenology (e.g. date of blooming or ripening of grapevine or ice phenology (e.g. date of freezing or melting of water bodies) (Pfister, 1999; Pfister et al., 1999).

A short text, part of a chronicle written by the Benedictine monk Jean de Stavelot, a contemporary eye witness from Liège contains both direct and indirect data ${ }^{1}$. The au-

\footnotetext{
${ }^{1}$ Item, en chi temporaile [...] fist si fort yviert et grant galée que la riviere de Mouze tresserat, et que de Jemeppe à Liege ons cherioit
} 
Table 1. Classification of documentary sources (Pfister et al., 2009; Camenisch, 2015).

\begin{tabular}{lll}
\hline & Institutional sources & Individual sources \\
\hline Narrative sources & - Annals & - Chronicles \\
& & - Memoirs \\
& & - Journals \\
& & - Letters \\
& & - Weather diaries \\
& & - Travel reports \\
\hline Administrative & - Monastic records & - Records of private households \\
sources & - Town records & \\
& - Toll accounts & \\
& - Charters &
\end{tabular}

thor gives not only an account of heavy frost in the winter of 1407/1408 but describes in addition how the Meuse was so firmly frozen between Jemeppe and Liège that chariots loaded with grain and other foods were driven on the ice. This frost lasted for 10 weeks before the ice started to melt on 28 January 1408 (the date is given in the Julian calendar style and in the Gregorian calendar equates to 7 February 1408).

Another distinction is made between institutional and individual sources on the one hand and between narrative and administrative sources on the other hand (see Table 1). The first classification takes note of the origination process of the text and the second focuses on the text type and its use (Pfister et al., 2009; Camenisch, 2015). Both have a direct impact on the quality of the sources, as discussed subsequently. Especially concerning the Late Middle Ages, chronicles, memoirs, and journals constitute individual narrative sources, whereas annals belong to the group of narrative sources but have institutional origins. The lines between the two groups are blurred since many texts show characteristics of both types (Geary, 2013). Amongst the administrative sources, bookkeeping accounts and charters (documents for legal purposes) of different origin are important to mention. In this paper, the first group was mainly used and charters did not play a major role. Also, administrative sources were generated either in an institutional setting such as in a monastery, town hall, and toll station or in a private individual setting (Camenisch, 2015).

The 15 th century is rich in narrative texts, mainly chronicles, annals, memoirs and journals. In the Burgundian Low Countries and the neighbouring regions a wealth of such manuscripts has been preserved and many of them have been published as edited books. The tradition of writing chronicles originates from antiquity and has survived for centuries in mostly a monastic or at least a clerical context (Rohr, 2007). The language of these texts is normally Medieval Latin (e.g. Balau, 1913; Dussart, 1892). Additionally, in the Late Middle Ages, interested laypeople wrote chronicles, some of them on

sus à charois bien chargiés de bleis ou d'aultres denrées; et durat celle galée plus de X semaines. [...] et chu fut l'an XIIIIc et VIII, le XXVIIIme jour de jenvier. (Borgnet, 1861) behalf of town authorities or nobles, others for more private purposes (Schmid, 2009, 2012). Those narrative texts were often written in a vernacular language. In the Burgundian Low Countries and the close neighbourhood, these languages were Middle Low German (e.g. Lamprecht et al., 1895; Cardauns et al., 1877), Middle Dutch (e.g. Kuys et al., 1983; De Jonghe, 1840; Fris, 1904) and Middle French (e.g. Borgnet, 1861; Tuetey, 1903) - each with local variations.

Usually, chronicles consist of a compilation of older texts followed by a second part composed by the chronicler and covering their lifespan. This second - contemporary - part is usually richer in information, more detailed and clearly more reliable. Some chroniclers summarise the crucial events year by year, while others write their text many years after the events (Lambert, 1993; van Caenegem, 1997). In narrative texts, the authors often describe weather conditions and especially extreme weather events because they could be a threat to the food supply or they were given religious significance (Ingram et al., 1981).

The reasons why weather conditions or proxy data are mentioned in administrative sources differ from those in narrative sources. The important source type of accounts is characterised by standardised records of costs and revenues. Either the climate proxies lead to costs or revenues and were listed for that purpose in the accounts, or short descriptions of weather conditions appear as justification for extraordinary costs (Wetter and Pfister, 2011; Pribyl et al., 2012). In this paper, narrative sources clearly form the main body of the data set and were the main focus of analysis. In addition, a number of edited town records (such as the De Stadsrekeningen van Arnhem for the first decades of the 15th century, Jappe Alberts, 1967, 1969, 1971, 1978, 1985) and further unedited town records relying on the Buisman $(1996,1998)$ compilations have been included in the data set.

\subsection{Critical source assessment}

A critical assessment for every source but also for each record is crucial for the quality of the entire reconstruction because the characteristics and quality of the sources 


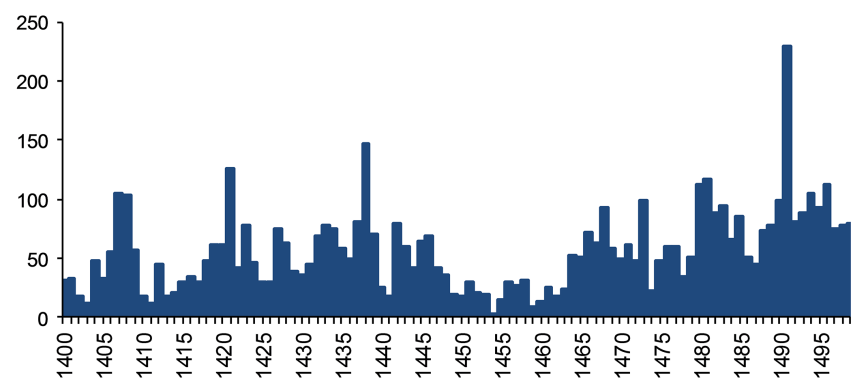

Figure 2. Annual distribution of the sources (Camenisch, 2015).

vary and they contain different types of information. Critical source assessment includes information on the author, especially dates of birth and death, the place where they lived and the context of their oeuvre (Alexandre, 1987). This information allows a distinction to be drawn between original text and copies of older manuscripts and is extremely important because of the significantly greater reliability of the records in the original (contemporary) part of the source. The closer the events occurred in relation to the time when the authors wrote their texts on paper or parchment, the more reliable they are. The best quality is given in the case of year-by-year reports. Records and journals and the final sections of annals and chronicles are usually produced in this way. If an event is convincingly proved by contemporary records, additional non-contemporary reports can be taken into account insofar as they confirm the main claim of contemporary evidence. Since each source has its own particularities that become clear by reading the text as a whole, it would be a fatal error just to pick the records from older or newer compilations without critical source and context assessment.

For this paper approximately 3000 records from about 100 sources were evaluated. Two-thirds of them are related to weather conditions, whereas the last third focuses on economic impacts caused by these weather conditions. Many of the records contain long descriptions.

\subsection{Source density}

The density of the sources is not equal throughout the entire century as Fig. 2 shows. Because of the different timespans of the sources not all decades have the same source density. In addition there is obviously more evidence in years with exceptional events, whereas years with average weather conditions were less documented, if they were described at all. This all depends on the quality of the sources covering the year in question and it is consequently the reason why years without enough evidence cannot simply be interpreted as average (see Sect. 4).

Within the calendar year the distribution of the records is almost equal in terms of winter (27\%), spring $(25.5 \%)$, and summer $(29.5 \%)$. In $18 \%$ of the records only autumn is less documented (Camenisch, 2015).
The distribution of the sources also differs with regard to their place of origin, as Fig. 3 shows. Most of the used sources have their origin in the Burgundian Low Countries but a number of texts derive from neighbouring areas and were included in the data set because of their excellent quality.

\subsection{Dating}

Confusion in dating is one of the most serious problems that can arise in a reconstruction. The reasons are closely linked to the fact that different calendar styles were in use during the particular epoch.

Before 1582 the Julian calendar style was in use in most Christian European countries. Since it is some minutes longer than the astronomical year, the calendrical beginning of the seasons diverged from the astronomic year. For many centuries the difference was barely observable. During the 15th century the deviation of the then 9 days was not only perceptible to experts in astronomy but also to those paying close attention (Schwarz-Zanetti, 1998; Borst, 2004; Grotefend, 1991). This means that in all texts, date indications deviate from the modern calendar style and need to be converted.

Another problem is derived from the fact that during the Middle Ages six possible days for the beginning of the calendar year exist: 1 January, 1 March, 25 March, Easter, 1 September and 25 December (Grotefend, 1991). The first of September is used rather seldom so one has to take care, especially concerning events occurring between Christmas and Easter. If one chronicle uses the Easter style and another one uses the Christmas style, the same events could have been be written down as having occurred in two different years. A clear analysis of the correct dating of events is indispensable, keeping in mind that the non-contemporary part of a narrative text is a copy of an older text probably with another calendar style. The authors of older weather compilations did not pay enough attention to these problems and even if they were aware of them, they usually did not give sufficient information on how they converted the dates. In this paper much effort was made to avoid such dating errors.

A very useful way to crosscheck the reliability of the dating of a certain narrative text is to search for records describing solar and lunar eclipses or comet observations. Many authors mention such observations because in medieval times they were seen as precursors to calamities (Rohr, 2013). The descriptions which appear in the narrative sources can be compared with catalogues of celestial events of the past (e.g. Kronk, 1999; Schroeter, 1923). 


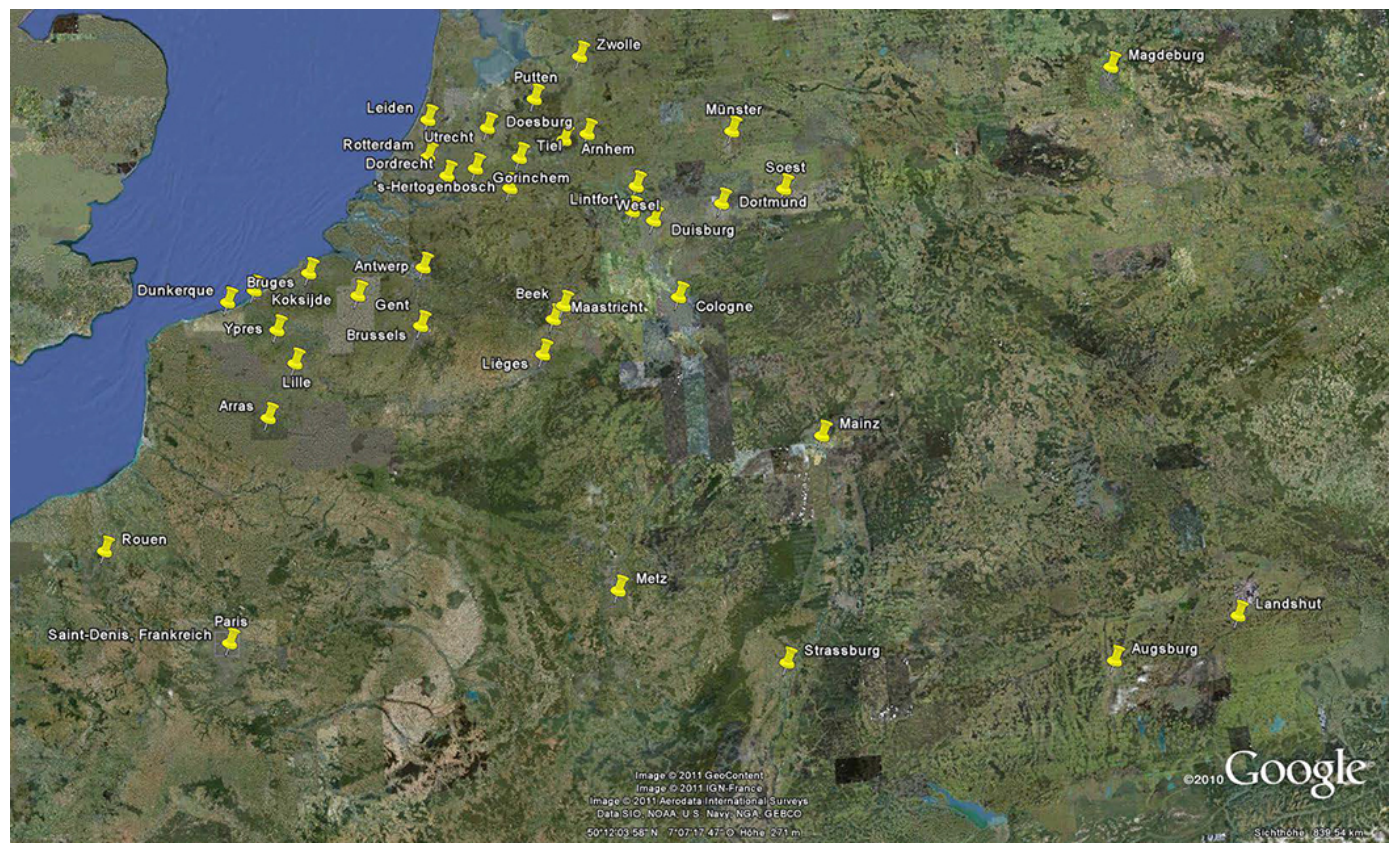

Figure 3. Geographical distribution of the origin of the sources.

Most of the medieval authors used ecclesiastical feast days in order to give precise dates within a year. Usually, this does not lead to problems. More challenging are descriptions that refer to seasons without more detail. In the past the meaning of the seasons was ambiguous (and still is to a certain degree). Medieval authors meant either astronomical seasons that changed at equinoxes and solstices or they used the name of the season to refer to the duration of typical weather patterns, agricultural work or phenological phenomena prevalent in that season (Pfister, 1988; Ogilvie and Farmer, 1997; Grotefend, 1991).

\section{Methodology}

As argued above, continuous, homogeneous, and quantitative series are required for climate reconstructions. Since several source types with different features and varying quality form the basis of this paper, an adequate method that can cope with these inhomogeneous data is required. Climate indices (so-called Pfister indices, Mauelshagen, 2010) offer a solution that enables the integration of all source types into one reconstruction. Pfister (1999) chose a scale of seven degrees because fewer degrees would not be detailed enough, whereas a more extended scale would in most cases lead to numerous gaps. There are separate indices for temperature and precipitation. Because of the remarkable source density in the late-medieval Burgundian Low Countries a seasonal resolution is adequate. This means the entire climate reconstruction is comprised of eight different indices. The meteorological year forms the basis of the seasonal subdivision of the indices. Therefore the winter season covers the period
Table 2. Scale of the climate indices (Pfister, 1999).

\begin{tabular}{lrl}
\hline Temperature indices & Index value & Precipitation indices \\
\hline Extremely warm & 3 & Extremely wet \\
Very warm & 2 & Very wet \\
Warm & 1 & Wet \\
Normal & 0 & Normal \\
Cold & -1 & Dry \\
Very cold & -2 & Very dry \\
Extremely cold & -3 & Extremely dry \\
\hline
\end{tabular}

from 1 December until 28 February, spring the period from 1 March until 31 May, summer from 1 June until 31 August and autumn from 1 September until 30 November.

Table 2 shows the scale of all indices. The reconstruction is realised in several steps. At the beginning of the process the sources are sorted into groups according to the seasons to which they refer. Preliminary analysis of the sources shows which kind of descriptions recur and how they can be evaluated on a seven-degree scale. Fundamental knowledge about the perception and interpretation of natural phenomena is indispensable to avoid misinterpretations (Rohr, 2007; Wegmann, 2005).

\subsection{Index criteria}

Specific criteria for each season and degree are defined and as many years as possible are given a value on the scale by a comparative interpretation of all data (Mauelshagen, 2010; Pfister, 1999). Since initial analysis probably causes a rather 
Table 3. Refined scale of the winter temperature index (Camenisch, 2015).

\begin{tabular}{|c|c|c|}
\hline Index value & Description & Criteria \\
\hline 3 & Extremely mild & $\begin{array}{l}\text { no frost or extremely few frost periods men- } \\
\text { tioned } \\
\text { considerable phenological anomalies } \\
\text { winter described as extremely mild }\end{array}$ \\
\hline 2 & Very mild & $\begin{array}{l}\text { almost no frost periods mentioned } \\
\text { remarkable phenological anomalies } \\
\text { winter described as mild }\end{array}$ \\
\hline 1 & Mild & $\begin{array}{l}\text { more rain than snow } \\
\text { little frost mentioned }\end{array}$ \\
\hline 0 & Normal & $\begin{array}{l}\text { few frosts } \\
\text { sporadic days with drifting ice }\end{array}$ \\
\hline-1 & Cold & $\begin{array}{l}\text { repeated periods with drifting ice } \\
\text { repeated frost periods }\end{array}$ \\
\hline-2 & Very cold & $\begin{array}{l}\text { small rivers or brooks frozen } \\
\text { frost mentioned over a period of about } 1 \text { month } \\
\text { plants damaged by frost }\end{array}$ \\
\hline-3 & Extremely cold & $\begin{array}{l}\text { large rivers and lakes frozen and passable } \\
\text { frost mentioned over a period of about } 2 \text { months } \\
\text { rye or trees damaged by frost }\end{array}$ \\
\hline
\end{tabular}

unequal distribution of the seasons, the criteria need to be refined and the process of source analysis started again. The refined criteria form the basis of the final reconstruction. However, the authors' preference for describing extreme events in the sources leads to a certain overrepresentation of those index values in the reconstruction.

Table 3 shows as an example the basic structure of the indices in the first row and the refined criteria for the reconstruction of the winter temperatures in the second row. The criteria include measurable or at least comparable physical and biological proxies (Pfister, 1999). Concerning the winter temperatures, this means for instance that in order to be assigned a value of -3 in the reconstruction, records on the freezing of large water bodies such as the Rhine, Scheldt, and Meuse or even the shores of the North Sea are required. This information does not indicate absolute temperatures since those water bodies freeze after the temperature sinks below a certain threshold, and it is not possible to determine the temperatures beneath that threshold (Pfister, 1999; Glaser, 2013). Similar are descriptions of frost damage to trees and winter crops. Only temperatures lower than $-30^{\circ} \mathrm{C}$ lead to bursting banks or the freezing of winter rye in the fields (Schubert, 2006).

More difficulties arise in reconstructing average or mild winter temperatures. For instance, the appearance of drifting ice is not comparable to present-day conditions because of extensive changes in the river beds, the increasing inflow of wastewater and the construction of canals. For milder tem- peratures, ice phenology cannot be taken into consideration. To a certain extent, plant phenology can offer valuables clues, but since there is no regular source of information on the same plants this method also has its limitations.

The analysis of winter precipitation before instrumental measurement records is challenging. The reason for this is that in the winter season precipitation often occurs as snowfall. It is extremely difficult to deduce the water content of snowfall only from descriptions. A further peculiarity of the contemporary descriptions is that in many cases the chroniclers do not clearly distinguish between the duration of snowfall and the timespan during which the snow cover did not melt, resulting in misinterpretations. In addition, floods are no clear indicator of the amount of precipitation because several causes exist and some of them, like ice jams and sudden snow melting, are linked to temperature (Wetter et al., 2011; Kiss, 2009). The chroniclers pay less attention to dryness and drought in winter. These are the reason why the winter precipitation index is less dense than the winter temperature index.

Concerning the climatic conditions during springtime, anomalies and extreme events are again overrepresented in the sources when compared with records of average conditions (see Fig. 5). In order to attribute a season the index value of -3 , it is necessary to have contemporary records of long frost periods or even frozen water bodies that last until springtime. Considerable deviations of plant phenology are also required. Some authors of narrative texts provide re- 
current information on the beginning of the growing season, which is very useful for the reconstruction of all degrees of the index scale.

Within the dataset no spring season can be assumed to be extremely wet (index value of -3 ). This is because in many cases only part of the spring season is described. For several years there is information on a given wet month but no information on the other two months so these years cannot definitively be allotted an extreme index value.

The refined criteria of the summer temperature reconstruction are related mostly to plant phenology. In particular, information on the growing of grapevines, grains or vegetables appears repeatedly in the texts and is very useful. Considerable deviations in the average phenology of those plants are necessary to obtain an index value of $+3,+2,-2$ or -3 . In order to allocate a summer season the index value of -1 , 0 or +1 descriptions without phenological deviations were sufficient.

For the reconstruction of summer precipitation the refined criteria are mostly linked to descriptions of damage caused by either dry or wet anomalies. Since a sufficient but not excessive amount of precipitation during summer is crucial for the harvest in the Low Countries, the medieval chroniclers paid it much attention. This is also the reason why the summer season is the best documented of the precipitation reconstructions. A certain problem arises from the fact that medieval authors often do not clearly distinguish between heat and drought, and the terms are used synonymously.

The autumn reconstruction contains the most extended gaps (see Fig. 7). The sources are silent, especially on the time after the grapevine harvest and the sowing of winter crops in September and October. This is the reason why information on this season often remains fragmentary and why it is very difficult to determine seasons that can be allocated the index values +3 and -3 . In the autumn reconstruction the precipitation index is denser than the temperature index because the sowing of winter crops was more vulnerable to precipitation than to temperature.

Generally, gaps originating from a lack of sources cannot be ascribed an "average" value for several reasons. Usually more than one record indicating the same tendency in the weather conditions is necessary in order to assign an index value. If there is contradictory information, the contemporary records are decisive. There are few cases when no contemporary records are available at all or some are plausible individually but contradictory as a whole. In such cases an index value was not set. This procedure leads to a more reliable reconstruction.

Since the data are inhomogeneous and no proxy would appear continuously for the whole century, there is no possibility of calibrating them with temperature or precipitation measurement of later times. After 1500, approaches to calibrate and verify indices with temperature and precipitation measurements exist (Dobrovolný et al., 2010, 2014).

\section{Reconstruction}

The climate reconstruction is comprised of four indices for each season concerning temperature and four indices concerning precipitation. The number of gaps in the indices varies and depends on the source density and the clear classification of the criteria defined for every index.

\subsection{Winter}

The temperature index for the winter season is the most complete of the reconstruction (see Fig. 4). Extremely cold (index value -3 ) and very cold (index value -2 ) temperatures are very well documented. The descriptions of many of these winters are rich and numerous. The winter of 1407/1408 for instance was one of the coldest in the century and the best documented season in the whole data set. Many chroniclers emphasised that no one could remember a winter like this. Jean Brandon, a monk at Ten Duinen Abbey on the Flemish coast, described this winter as dry and cold. Such low temperatures and chilly frost had not occurred for 100 years prior, as the Flemish monk affirms in his text (Kervyn de Lettenhove, $1870)^{2}$.

Thanks to the excellent source density, different phases of cold can be identified in the weather conditions of these months. Around the feast of Saint Martin on 11 November 1407 (20 November converted into Gregorian calendar style) the sink in temperatures was widespread, as is reported in texts from Liège, Paris, Cologne, Lübeck, Magdeburg and Dortmund (Camenisch, 2015). Another cold front reached the Burgundian Low Countries some days after the beginning of December (Gregorian calendar style - all following data are converted into this style). Several water bodies froze after Christmas, such as the Seine, the Rhine and the Meuse with its tributary stream, the Sambre. The ice cover was thick enough for people to ride horses on it and drive loaded chariots from one river bank to the other (Camenisch, 2015). Further away, Lake Zurich and Lake Constance were also frozen (Brunner, 2004).

At the end of January a few days with milder temperatures led to the breakup of ice cover on the rivers (around 6 January in Paris, for example). The drifting ice jammed the rivers in Paris and Liège, flooding the river banks. According to most chroniclers the frost ended around the beginning of February. The winter crops perished in Flanders because of the frost (and the lack of protective snow cover). In Paris, vineyards and fruit trees were damaged by the same frost. Moreover, people, cattle and birds fell victim to the extremely low temperatures.

For more average winters (index values of $-1,0$ or +1 ) fewer sources exist. During the 15th century, three clusters of very cold and extremely cold winters can be detected.

\footnotetext{
21407 [...] Hoc anno [...] hyemps sicca et frigida, ita ut gelu asperum esset a principio decembris usque in finem januarii, ut a $\mathrm{C}$ annis tantum frigus et tantum gelu non fuerit.
} 


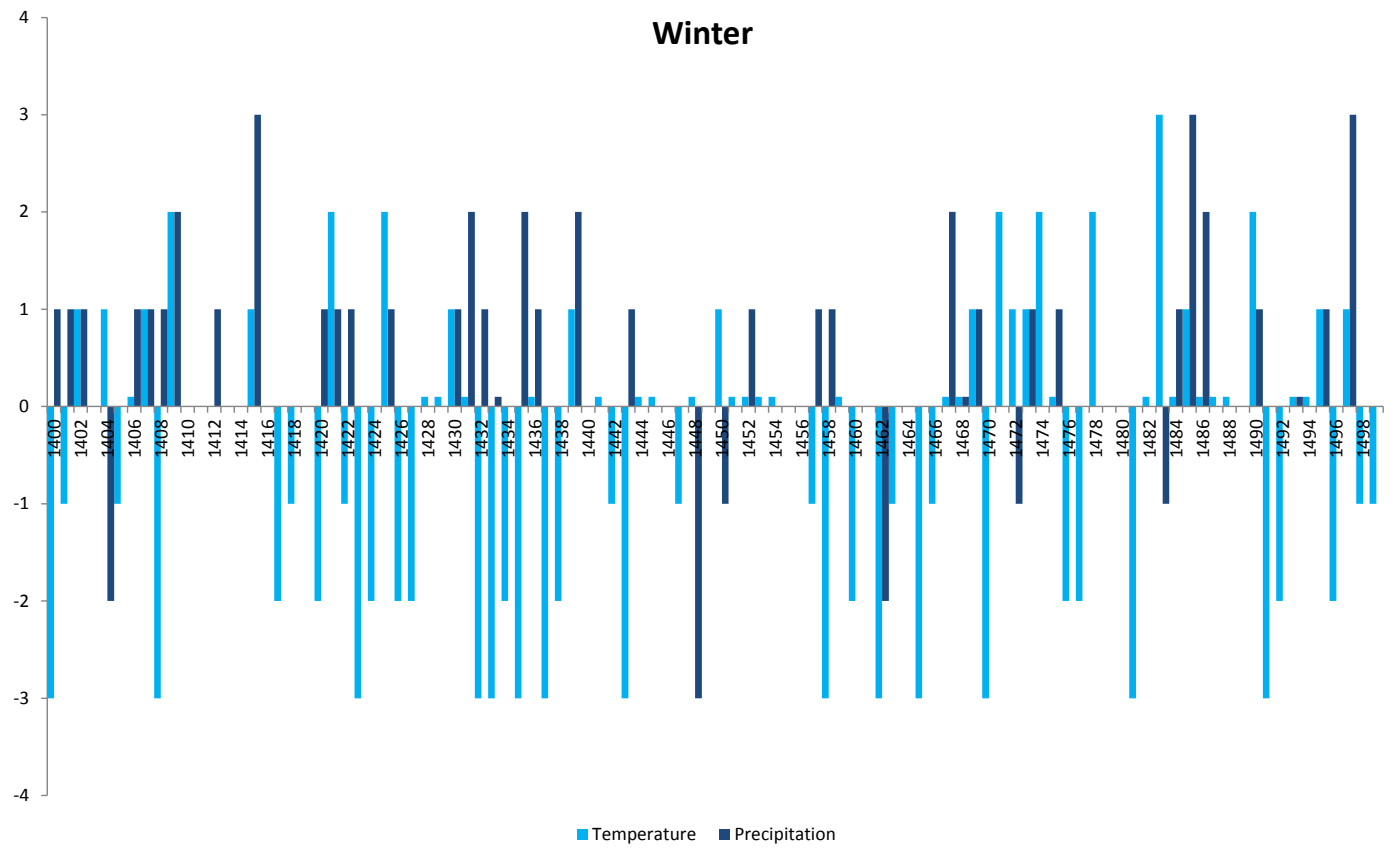

Figure 4. Winter indices.

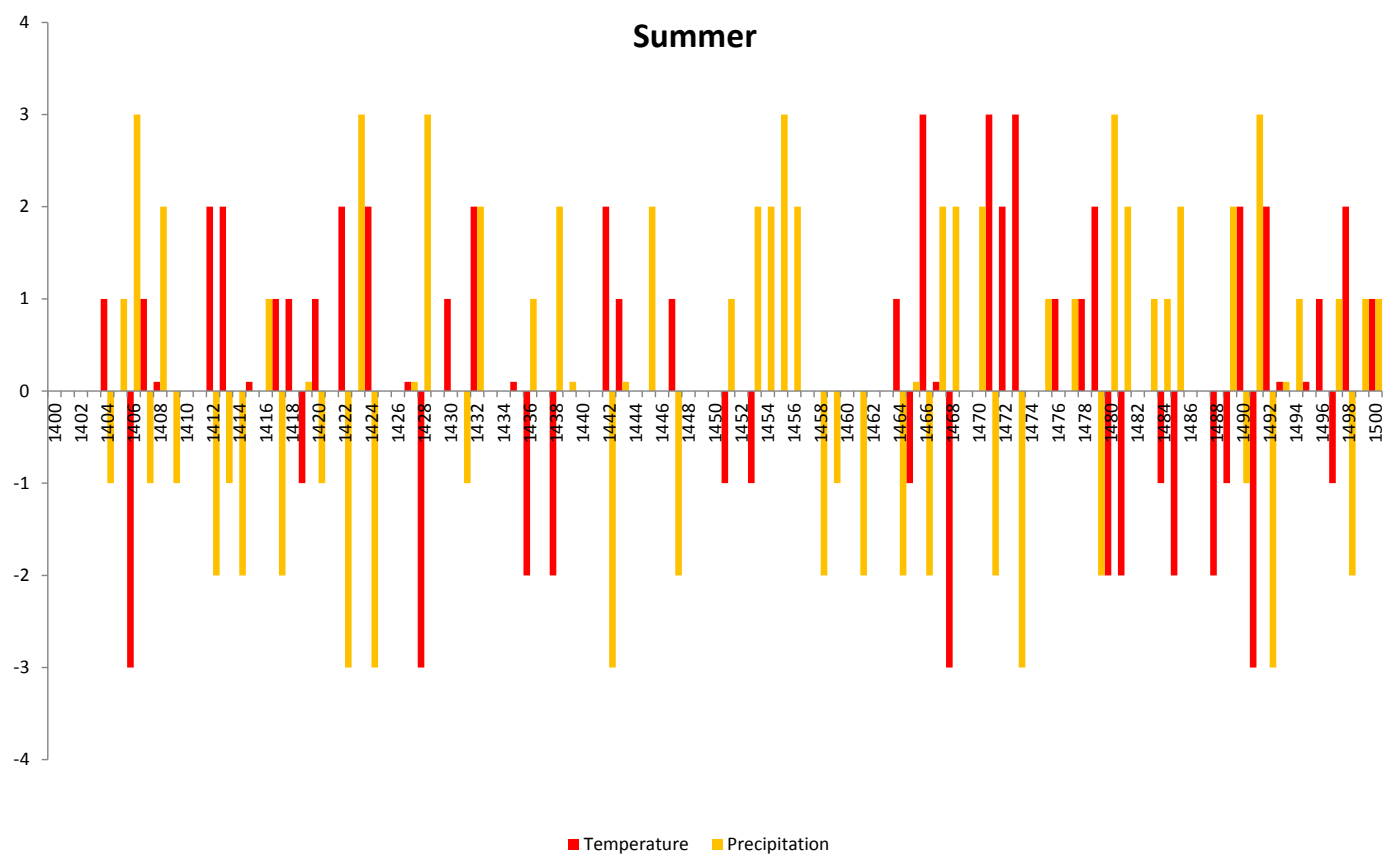

Figure 5. Spring indices.

The clusters during the 1420 s and during the 1460 s are remarkable but that of the 1430 s is especially exceptional. This decade is one of the coldest of the whole millennium if not the very coldest (Lamb, 1982). In contrast are the extremely or very mild winters of the first half of the 1470s and the beginning of the 1480s. Less is known about the winter seasons of the middle of the century, especially the 1440s and 1450s because of the lack of contemporary sources.

Concerning precipitation, medieval records are rather silent in the first years of the century. As a consequence there is a remarkable gap in the reconstruction from 1410 to 1417. In addition, the second half of the 1430s, the last years of the 
1440 s and the 1450s in general are difficult to assess for the same reasons.

Only one extremely dry (1447/1448) and a few very dry winter seasons could be identified during the 15th century. Three years with extremely wet seasons are known $(1414 / 1415,1484 / 1485,1496 / 1497)$. Accumulations of very wet and wet winter seasons can be observed in the first decade of the century, at the beginning of the 1420 s and 1430 s and in the middle of the 1480s.

\subsection{Spring}

A cluster of cold anomalies (index values of -3 and -2 ) can be detected during the second half of the 1420s, the 1430s and the last 2 decades of the century, similarly to the winter reconstruction. Warm anomalies prevailed during the $1460 \mathrm{~s}$ and 1470s. The years 1432, 1443, 1446, 1481 and 1492 are reported to be years with extremely low temperatures (index value -3 ), whereas the spring seasons of the years 1420 and 1473 stood out for their extremely warm temperatures (index value +3$)$.

No spring season has been proven to be extremely wet (index value -3). Also, at the other end of the scale, in the 15th century, only the year 1424 was determined to be an extremely dry spring season. Very wet, wet, average, dry and very dry seasons are spread throughout the century. Only the 1440s included two very dry spring seasons, and in 1427 and 1428 very wet spring seasons occurred.

\subsection{Summer}

The prevailing weather conditions of the summer seasons are better documented than those of the spring seasons (see Fig. 6). This is due to the preference of medieval authors to describe weather conditions during periods when much agricultural work had to be done. As a consequence fewer gaps exist in the two summer indices. Nonetheless, there is a lack of information at the beginning of the century and during the 1450s. Apart from that, shorter gaps are spread throughout the whole century. In 1406, 1428 and 1468 the weather conditions were extremely cold, whereas extremely warm summer seasons (index value -3 ) are reported in the years 1466 , 1471, 1473 and 1491. The year 1473 stands out by virtue of its extremely high temperatures, possibly topped only by the year 1540 (Wetter et al., 2014). A cluster of warm anomalies at the beginning of the 1470s and clusters of cold anomalies during the 1480s and at the beginning of the subsequent decade are also remarkable.

Extremely dry years (index value -3 ) were 1422, 1424, 1442,1473 and 1492. Extremely wet seasons (index value +3 ) were the summers in 1406, 1423, 1428, 1455, 1480 and 1491. Obviously there were extremes on both sides of the scale during the $1420 \mathrm{~s}$. A cluster of dry anomalies is documented during the 1450 s, a decade rather lacking in records.

\subsection{Autumn}

The indices for autumn temperatures and precipitation are the least dense in the climate reconstruction. Fewer seasons are found at either end of the scale because in many cases there is only information on part of the season. Consequently, 1468 is the only autumn season with index value -3 in the temperature reconstruction, whereas at the other end of the scale the year 1487 fulfilled the criteria for index value +3 . During the 1480s there was a clustering of cold and very cold autumn seasons.

Extremely dry (index value -3 ) autumn seasons occurred in the years 1442 and 1473. The years 1405, 1423, 1468, 1483 and 1491 can be awarded index value +3 . Towards the end of the century wet and very wet autumn seasons prevailed. However, in both indices there are many gaps during the 1430s, 1450s and 1460s.

\section{Prevailing weather conditions of the 15th century}

The first decade of the 15 th century was characterised by rather average temperatures with the exception of the extremely cold winter seasons in 1399/1400 and 1407/1408 and the extremely cold summer of 1406 . Also, with regard to precipitation, most years are within the average, apart from autumn 1405 and summer 1406, which were extremely wet, the very wet spring in 1404, summer in 1408 and winter in $1408 / 1409$ and the very dry seasons in winter 1403/1404, autumn 1404 and spring 1409. There is not much information available for the subsequent decade concerning temperatures and most known seasons were average. However, in 1412 and 1413 there were very warm temperatures in the summer season and in 1416/1417 the winter temperatures were reported as very cold. Regarding precipitation, the period from autumn 1414 to spring 1415 needs to be mentioned for its above-average wet seasons. The winter season of 1414/1415 was also extremely wet.

A considerable number of very cold and one extremely cold $(1422 / 1423)$ winter seasons can be identified in the 1420s. Very cold spring temperatures are reported for 1421 and 1427, as well as a very cold summer in 1428. In 1420 there was an extremely warm summer, whereas very warm and mild temperatures occurred in winter 1420/1421 and summer 1422 and 1424 .

The 1430s were an exceptional decade of the 15 th century. The majority the winter seasons were extremely cold or at least very cold and a considerable number of spring seasons had the same characteristics. This remarkable temperature cluster, together with other cold periods in the 15th century, is responsible for the title chosen: "endless cold". Horace Hubert Lamb suggested, with regard to the winter temperatures, that the 1430s and the 1690s constitute the coldest episodes of the last millennium (Lamb, 1982). Very recent research even associates this decade with an early phase of the Spörer Minimum (Camenisch et al., 2014). There is 


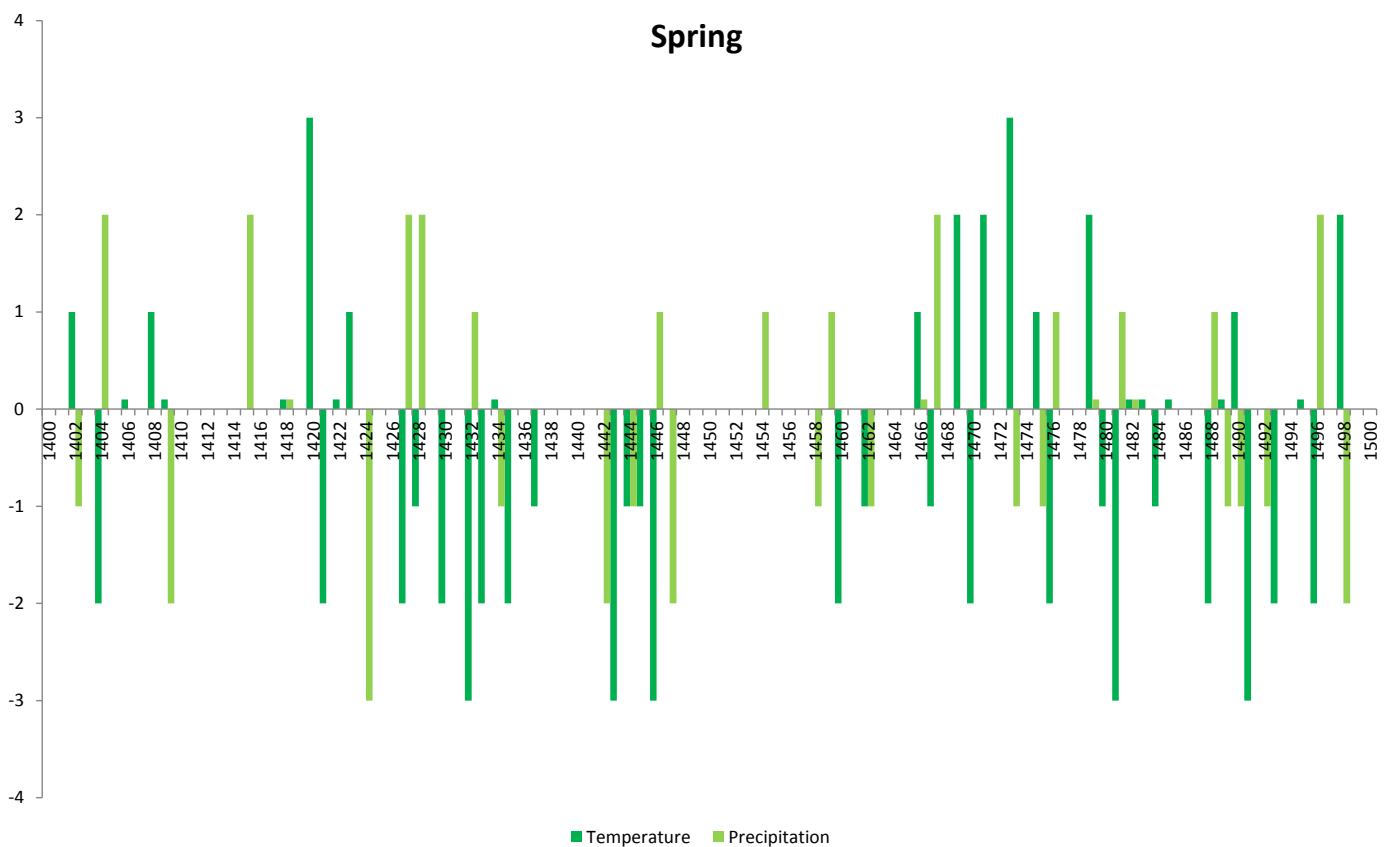

Figure 6. Summer indices.

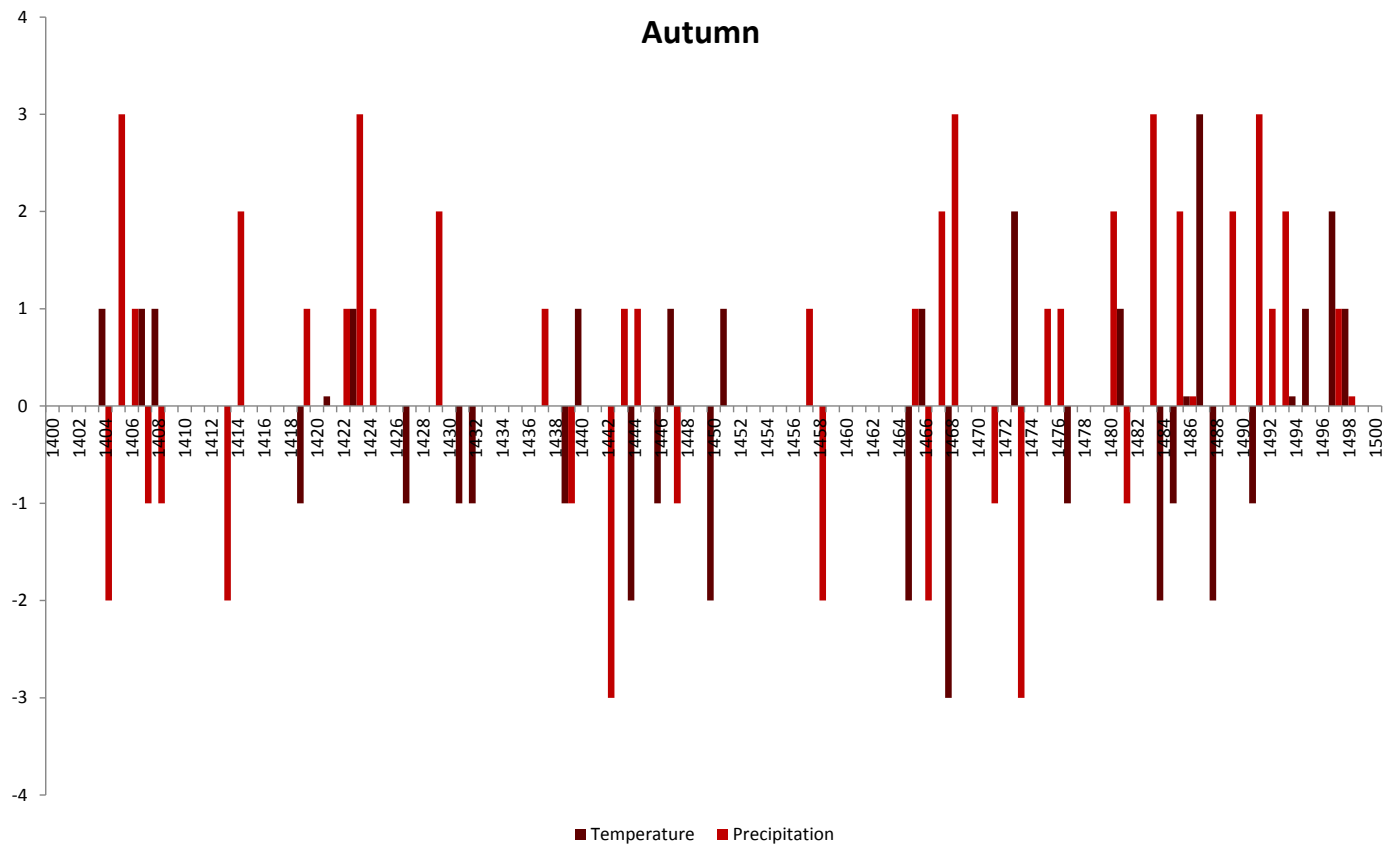

Figure 7. Autumn indices.

less information about summer temperatures because they were not as remarkable as the winter and spring temperatures. However, in 1432 there was a very warm summer and in 1436 and 1438 the summer temperatures were very cold. In the same decade a number of above-average wet seasons occurred such as winter 1430/1431, winter 1434/1435, summer 1432 and summer 1438.
During the 1440 s, there were three extremely cold seasons in winter 1442/1443, in the subsequent spring 1443 and in spring 1446, and one very cold season in autumn 1444. Only in summer 1442 were temperatures very warm. The decade was characterised by rather dry weather conditions in the Burgundian Low Countries, especially in 1442, 1447 and 1448. There are fewer sources available which de- 
scribe the 1450s. However, there is a remarkable cluster of above-average wet summer seasons from 1453 until 1456. There is more information on the subsequent decade. Winter $1461 / 1462$ was extremely cold and very dry; in 1465 there was a second extremely cold winter. In the following year temperatures in summer were extremely warm and it was very dry until autumn. Moreover, in 1468 occurred an extremely cold and wet summer followed by an autumn with the same weather conditions.

The 1470s are a decade with warm anomalies in the summer season. Weather conditions were predominantly dry and warm in the years from 1471 to 1473 and again in 1479 . At the very beginning of the decade there was an extremely cold winter followed by a very cold spring. Also from winter $1476 / 1477$ to spring 1477 and in winter $1477 / 1478$ belowaverage temperatures prevailed. During the last 2 years of the decade, warm spells again become more frequent.

At the beginning and at the end of the 1480s remarkable cold and wet weather conditions need to be mentioned. In particular the period from summer 1480 to summer 1481 was exceptional because of an above-average amount of precipitation and considerably low temperatures. In contrast, the winter of 1483 experienced extremely mild temperatures. The below-average temperatures of 1488 returned again in 1491 when almost the whole year was characterised by extremely cold weather conditions. With regard to precipitation the wet anomalies in summer 1491 and winter 1496/1497 need to be mentioned as well as the drought in summer 1492 .

\section{Discussion}

Comparison of the indices presented herein with a number of other reconstructions was made. The winter (NDJFM) and summer (MJJAS) temperature indices by Shabalova and van Engelen (2003), van Engelen et al. (2001) and Buisman $(1995,1996,1998,2000,2006,2015)$ for the Netherlands are based on documentary evidence and are the closest reconstruction regarding methods (nine-degree indices) and geographical coverage. Nonetheless, there are differences because the winter (DJF) and summer (JJA) temperature indices presented in this paper and the van Engelen indices do not cover exactly the same months and the van Engelen indices have considerably fewer gaps, especially in summer. However, the Pearson correlation coefficients are remarkably high. Regarding the winter temperatures, a coefficient $(r)$ of $-0.893(N=81 ; p<0.01$, the van Engelen indices equate to the winter indices presented here) and as regards the summer temperatures a coefficient of $0.783(N=50 ; p<0.01)$ shows the close relationship between the two reconstructions. The relationhip between the van Engelen summer temperature index and the presented summer precipitation in$\operatorname{dex}(r=0.792 ; N=60 ; p<0.01)$, spring temperature index $(r=0.465 ; N=46 ; p<0.01)$, and spring precipitation in$\operatorname{dex}(r=0.585 ; N=31 ; p<0.01)$ is also remarkably close.
Litzenburger (2015) recently presented a further climate reconstruction from Metz (Lorraine, France) based on documentary data and containing seasonal temperature and precipitation indices. A comparison of the two reconstructions shows remarkable similarities. The summer temperatures $(r=0.844 ; N=40 ; p<0.01)$ and autumn precipitation $(r=0.708 ; N=31 ; p<0.01)$ are very close. Also rather similar are winter temperatures $(r=0.658$; $N=70 ; p<0.01)$, spring temperatures $(r=0.671 ; N=41$; $p<0.01)$ and precipitation $(r=0.609 ; N=27 ; p<0.01)$ and summer precipitation $(r=0.641 ; N=48 ; p<0.01)$, though $N$ is rather low in some parts of the analyses. The comparison of the annual temperature (obtained by summing the seasonal indices as Pfister and Brázdil, 1999, suggest) and precipitation series show even higher correlations (see Fig. 8). The most obvious difference occurs during the 1450 s, when the indices presented here are much closer to the average than Litzenburger's. This is because the former indices have many gaps in this decade, producing a rather average and misleading result regarding the summed indices for the whole year.

Comparison with the indices presented by Glaser and Riemann (2009) shows weaker correlations. The closest relationships exist between the summer temperature indices $(r=0.494 ; N=50 ; p<0.01)$, the spring temperature indices $(r=0.415 ; N=47 ; p<0.01)$ and the winter temperature indices $(r=0.393 ; N=82 ; p<0.01)$. The reason for this is probably the greater distance between the two researched areas and the different scales of the indices because Glaser applies a three-degree scale for the 15th century.

Furthermore, the indices presented here were compared with the grape harvest dates and spring-summer reconstruction for Burgundy presented by Chuine et al. (2004). Also, in this case the results show a strong relationhip between the Chuine et al. data and the indices presented here. The grape harvest dates are sensitive to spring and summer temperatures. The highest Pearson correlation coefficients were obtained in comparison with these indices (spring temperatures: $r=0.521 ; N=47 ; p<0.01$ and summer temperatures: $r=0.637 ; N=50 ; p<0.01)$. Obviously, the summer precipitation index is also rather similar $(r=0.548 ; N=60$; $p<0.01$ ). In addition, a certain relationship, albeit with a weaker level of significance, is established between the grape harvest dates and the spring precipitation $(r=0.435$; $N=32 ; p<0.05)$ and the autumn precipitation $(r=0.348$; $N=39 ; p<0.05)$. The results of the comparison with the Chuine et al. data are very important as these data were obtained from completely independent methods and sources. The Litzenburger, van Engelen and Glaser indices were also produced independently but the applied method and a number of sources are very similar to the indices presented here.

Comparison between the indices and the reconstruction by Büntgen et al. (2011) shows only weak similarities. The considerable distance between the two researched areas and 


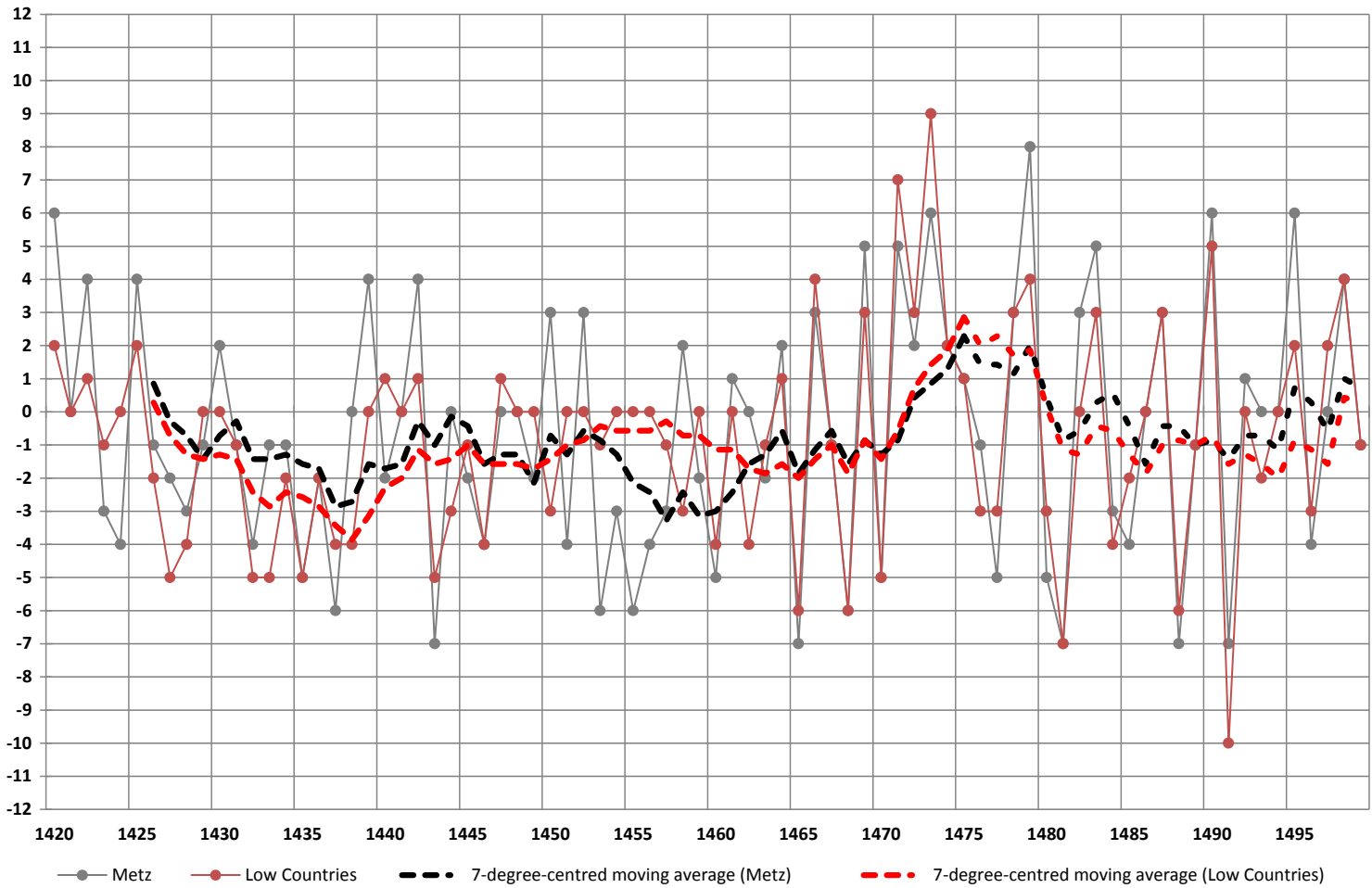

Figure 8. Comparison between temperature indices from Metz (Litzenburger, 2015) and the Low Countries (Camenisch, 2015).

the completely different methods are probably the reason for this.

\section{Conclusions}

This paper gives an overview of seasonal temperature and precipitation during the 15 th century. The reconstruction contains eight climate indices (separate indices on temperature and precipitation for every season) based on documentary evidence. The main body of the data set consists of narrative sources such as chronicles, annals, memoirs or journals and administrative sources such as accounts. These sources have individual and institutional backgrounds. The sources contain either direct data and/or indirect data (proxy data that can be converted into climate indices). The basis of the indices is a seven-degree scale starting with -3 for extremely cold or extremely dry conditions and going up to +3 for extremely warm or extremely wet conditions. A catalogue of criteria was defined for every index value in order to evaluate as many seasons as possible. The indices for winter temperatures, summer temperatures and summer precipitation are the most complete. During the 15 th century a number of exceptional weather patterns can be detected. Therefore, more attention should be paid to the climate of this century, as it is an interesting period, which has not yet been sufficiently examined. Most remarkable are a cluster of extremely cold winter temperatures during the $1430 \mathrm{~s}$ - the reason for the first part of the title - as well as an extremely cold winter in 1407/1408. This cluster of cold winters has been underestimated in recent research. A number of dry and hot spells occurred; amongst them the year 1473 was unique because of the extent and duration of the heat and the lack of precipitation. Extremely wet weather conditions especially in summer were prevalent at the beginning and the end of the 1480s and at the beginning of the 1490s. Comparison with Dutch and French reconstructions shows very satisfactory results.

The climate indices in Appendix A will provide the basis for further research with regard to climate impacts on human society. 


\section{Appendix A: Climate indices}

Table A1. Climate indices.

\begin{tabular}{|c|c|c|c|c|c|c|c|c|}
\hline \multirow[t]{2}{*}{ Year } & \multicolumn{2}{|c|}{ Winter } & \multicolumn{2}{|c|}{ Spring } & \multicolumn{2}{|c|}{ Summer } & \multicolumn{2}{|c|}{ Autumn } \\
\hline & Temp. & Prec. & Temp. & Prec. & Temp. & Prec. & Temp. & Prec. \\
\hline 1400 & -3 & 1 & & & & & & \\
\hline 1401 & -1 & 1 & & & & & & \\
\hline 1402 & 1 & 1 & 1 & -1 & & & & \\
\hline 1403 & & & & & & & & \\
\hline 1404 & 1 & -2 & -2 & 2 & 1 & -1 & 1 & -2 \\
\hline 1405 & -1 & & & & & 1 & & 3 \\
\hline 1406 & 0 & 1 & 0 & & -3 & 3 & & 1 \\
\hline 1407 & 1 & 1 & & & 1 & -1 & 1 & -1 \\
\hline 1408 & -3 & 1 & 1 & & 0 & 2 & 1 & -1 \\
\hline 1409 & 2 & 2 & 0 & -2 & & -1 & & \\
\hline 1410 & & & & & & & & \\
\hline 1411 & & & & & & & & \\
\hline 1412 & & 1 & & & 2 & -2 & & \\
\hline 1413 & & & & & 2 & -1 & & -2 \\
\hline 1414 & & & & & & -2 & & 2 \\
\hline 1415 & 1 & 3 & & 2 & 0 & & & \\
\hline 1416 & & & & & & 1 & & \\
\hline 1417 & -2 & & & & 1 & -2 & & \\
\hline 1418 & -1 & & 0 & 0 & 1 & & & \\
\hline 1419 & & & & & -1 & 0 & -1 & 1 \\
\hline 1420 & -2 & 1 & 3 & & 1 & -1 & & \\
\hline 1421 & 2 & 1 & -2 & & & & 0 & \\
\hline 1422 & -1 & 1 & 0 & & 2 & -3 & & 1 \\
\hline 1423 & -3 & & 1 & & & 3 & 1 & 3 \\
\hline 1424 & -2 & & & -3 & 2 & -3 & & 1 \\
\hline 1425 & 2 & 1 & & & & & & \\
\hline 1426 & -2 & & & & & & & \\
\hline 1427 & -2 & & -2 & 2 & 0 & 0 & -1 & \\
\hline 1428 & 0 & & -1 & 2 & -3 & 3 & & \\
\hline 1429 & 0 & & & & & & & 2 \\
\hline 1430 & 1 & 1 & -2 & & 1 & & & \\
\hline 1431 & 0 & 2 & & & & -1 & -1 & \\
\hline 1432 & -3 & 1 & -3 & 1 & 2 & 2 & -1 & \\
\hline 1433 & -3 & 0 & -2 & & & & & \\
\hline 1434 & -2 & & 0 & -1 & & & & \\
\hline 1435 & -3 & 2 & -2 & & 0 & & & \\
\hline 1436 & 0 & 1 & & & -2 & 1 & & \\
\hline 1437 & -3 & & -1 & & & & & 1 \\
\hline 1438 & -2 & & & & -2 & 2 & & \\
\hline 1439 & 1 & 2 & & & & 0 & -1 & -1 \\
\hline 1440 & & & & & & & 1 & \\
\hline 1441 & 0 & & & & & & & \\
\hline 1442 & -1 & & & -2 & 2 & -3 & & -3 \\
\hline 1443 & -3 & 1 & -3 & & 1 & 0 & & 1 \\
\hline 1444 & 0 & & -1 & -1 & & & -2 & 1 \\
\hline 1445 & 0 & & -1 & & & 2 & & \\
\hline 1446 & & & -3 & 1 & & & -1 & \\
\hline 1447 & -1 & & & -2 & 1 & -2 & 1 & -1 \\
\hline 1448 & 0 & -3 & & & & & & \\
\hline 1449 & & & & & & & & \\
\hline 1450 & 1 & -1 & & & & & -2 & \\
\hline
\end{tabular}


Table A1. Continued.

\begin{tabular}{|c|c|c|c|c|c|c|c|c|}
\hline \multirow[t]{2}{*}{ Year } & \multicolumn{2}{|c|}{ Winter } & \multicolumn{2}{|c|}{ Spring } & \multicolumn{2}{|c|}{ Summer } & \multicolumn{2}{|c|}{ Autumn } \\
\hline & Temp. & Prec. & Temp. & Prec. & Temp. & Prec. & Temp. & Prec. \\
\hline 1451 & 0 & & & & -1 & 1 & 1 & \\
\hline 1452 & 0 & 1 & & & & & & \\
\hline 1453 & 0 & & & & -1 & 2 & & \\
\hline 1454 & 0 & & & 1 & & 2 & & \\
\hline 1455 & & & & & & 3 & & \\
\hline 1456 & & & & & & 2 & & \\
\hline 1457 & -1 & 1 & & & & & & 1 \\
\hline 1458 & -3 & 1 & & -1 & & -2 & & -2 \\
\hline 1459 & 0 & & & 1 & & -1 & & \\
\hline 1460 & -2 & & -2 & & & & & \\
\hline 1461 & & & & & & -2 & & \\
\hline 1462 & -3 & -2 & -1 & -1 & & & & \\
\hline 1463 & -1 & & & & & & & \\
\hline 1464 & & & & & 1 & -2 & & \\
\hline 1465 & -3 & & & & -1 & 0 & -2 & 1 \\
\hline 1466 & -1 & & 1 & 0 & 3 & -2 & 1 & -2 \\
\hline 1467 & 0 & 2 & -1 & 2 & 0 & 2 & & 2 \\
\hline 1468 & 0 & 0 & & & -3 & 2 & -3 & 3 \\
\hline 1469 & 1 & 1 & 2 & & & & & \\
\hline 1470 & -3 & & -2 & & & 2 & & \\
\hline 1471 & 2 & & 2 & & 3 & -2 & & -1 \\
\hline 1472 & 1 & -1 & & & 2 & & & \\
\hline 1473 & 1 & 1 & 3 & -1 & 3 & -3 & 2 & -3 \\
\hline 1474 & 2 & & & & & & & \\
\hline 1475 & 0 & 1 & 1 & -1 & & 1 & & 1 \\
\hline 1476 & -2 & & -2 & 1 & 1 & & & 1 \\
\hline 1477 & -2 & & & & & 1 & -1 & \\
\hline 1478 & 2 & & & & 1 & & & \\
\hline 1479 & & & 2 & 0 & 2 & -2 & & \\
\hline 1480 & & & -1 & & -2 & 3 & & 2 \\
\hline 1481 & -3 & & -3 & 1 & -2 & 2 & 1 & -1 \\
\hline 1482 & 0 & & 0 & 0 & & & & \\
\hline 1483 & 3 & -1 & 0 & & & 1 & & 3 \\
\hline 1484 & 0 & 1 & -1 & & -1 & 1 & -2 & \\
\hline 1485 & 1 & 3 & 0 & & -2 & 2 & -1 & 2 \\
\hline 1486 & 0 & 2 & & & & & 0 & 0 \\
\hline 1487 & 0 & & & & & & 3 & \\
\hline 1488 & 0 & & -2 & 1 & -2 & & -2 & \\
\hline 1489 & & & 0 & -1 & -1 & 2 & & 2 \\
\hline 1490 & 2 & 1 & 1 & -1 & 2 & -1 & & \\
\hline 1491 & -3 & & -3 & & -3 & 3 & -1 & 3 \\
\hline 1492 & -2 & & & -1 & 2 & -3 & & 1 \\
\hline 1493 & 0 & 0 & -2 & & 0 & 0 & & 2 \\
\hline 1494 & 0 & & & & & 1 & 0 & \\
\hline 1495 & 1 & 1 & 0 & & 0 & & 1 & \\
\hline 1496 & -2 & & -2 & 2 & 1 & & & \\
\hline 1497 & 1 & 3 & & & -1 & 1 & 2 & 1 \\
\hline 1498 & -1 & & 2 & -2 & 2 & -2 & 1 & 0 \\
\hline 1499 & -1 & & & & & 1 & & \\
\hline
\end{tabular}


Acknowledgements. Acknowledgements are given to the Swiss National Foundation, the Historical Institute of the University of Bern and the Oeschger Centre for Climatic Change Research for funding support. Heli Huhtamaa, Oliver Wetter, and Christian Pfister (University of Bern) are thanked for their advice. Many thanks to Marco Zanoli for providing the map of the Burgundian Low Countries and to Laurent Litzenburger for Fig. 8.

Edited by: J. Luterbacher

\section{References}

Aberth, J.: An environmental history of the Middle Ages. The crucible of nature, Routledge, London, 2013.

Alexandre, P.: Le climat en Europe au Moyen Âge. Contribution à l'histoire des variations climatiques de 1000 à 1425 , d'après les sources narratives de l'Europe occidentale, Recherches d'histoire et de sciences sociales, 24, Éditions de l'École des Hautes Études en Sciences Sociales, Paris, 1987 (in French).

Allen, R. C.: Economic structure and agricultural productivity in Europe. 1300-1800, Eur. Rev. Econ. Hist., 3, 1-25, 2000.

Balau, S. (Ed.): Jean de Stavelot, Chronique latine, Chroniques Liégeoises, 1, Collection de chroniques belges inédites et de documents inédits relatifs à l'histoire de la Belgique 40, Brussels, 67-143, 1913 (in Latin).

Behringer, W.: A cultural history of climate, Polity Press, Cambridge, 2010.

Blockmans, W. P. and Prevenier, W.: The promised lands. The Low Countries under Burgundian rule 1369-1530, University of Pennsylvania Press, Philadelphia, 1999.

Borgnet, A. (Ed.): Chroniques de Jean de Stavelot, Collection de Chroniques Belges, 1, Hayez, Brussels, 1861 (in French).

Borst, A.: Computus, Zeit und Zahl in der Geschichte Europas, 3rd Edn., Wagenbach, Berlin, 2004 (in German).

Brázdil, R. and Kotyza, O.: History of weather and climate in the Czech Lands, Vol. 1, Period 1000-1500, Zürcher Geographische Schriften, 62, Geographisches Institut ETH, Zurich, 1995.

Brázdil, R., Pfister, C., Wanner, H., von Storch, H., and Luterbacher, J.: Historical climatology in Europe - The state of the art, Climatic Change, 70, 363-430, 2005.

Brázdil, R., Kotyza, O., Dobrovolný, P., Řezníčková, L., and Valášek, H.: Climate of the sixteenth century in the Czech Lands, Masaryk University, Brno, 2013.

Britton, C. E.: A meteorological chronology to A.D. 1450, Great Britain Meteorological Office, Geophysical Memoirs, 70, His Majesty's Stationery Office, London, 1937.

Brooke, J. L.: Climate change and the course of global history. A rough journey, Cambridge University Press, New York, 2014.

Brunner, K.: Die Seegfrörnen des Bodensees. Eine Dokumentation in Bilddarstellungen, Schriften des Vereins für Geschichte des Bodensees und seiner Umgebung, 122, 71-84, 2004 (in German).

Buisman, J.: Duizend jaar weer, wind en water in de Lage Landen, 1 (1000-1300), ed. by van Engelen, A. F. V., Van Wijnen, Franeker, 1995 (in Dutch).

Buisman, J.: Duizend jaar weer, wind en water in de Lage Landen, 2 (1300-1450), edited by: van Engelen, A. F. V., Van Wijnen, Franeker, Netherlands, 1996 (in Dutch).
Buisman, J.: Duizend jaar weer, wind en water in de Lage Landen, 3 (1450-1575), edited by: van Engelen, A. F. V., Van Wijnen, Franeker, Netherlands, 1998 (in Dutch).

Buisman, J.: Duizend jaar weer, wind en water in de Lage Landen, 4 (1575-1675), edited by: van Engelen, A. F. V., Van Wijnen, Franeker, Netherlands, 2000 (in Dutch).

Buisman, J.: Duizend jaar weer, wind en water in de Lage Landen, 5 (1675-1750), edited by: by van Engelen, A. F. V., Van Wijnen, Franeker, Netherlands, 2006 (in Dutch).

Buisman, J.: Extreem weer! Een canon van weergaloze winters and zinderende zomers, hagel and hozen, stormen and watersnoden, Van Wijnen, Franeker, Netherlands, 2011 (in Dutch).

Buisman, J.: Duizend jaar weer, wind en water in de Lage Landen, 5 (1750-1800), edited by: van Engelen, A. F. V., Van Wijnen, Franeker, Netherlands, 2015 (in Dutch).

Büntgen, U., Tegel, W., Nicolussi, K., McCormick, M., Frank, D., Trouet, V., Kaplan, J. O., Herzig, F., Heussner, K.-U., Wanner, H., Luterbacher, J, and Esper, J.: 2500 years of European climate variability and human susceptibility, Science, 331, 578583, 2011.

Calmette, J.: Die grossen Herzöge von Burgund, Diederichs, München, (Original: Grands ducs de Bourgogne, Albin Michel, Paris, 1949), 1996 (in German).

Camenisch, C.: Endlose Kälte. Witterungsverlauf und Getreidepreise in den burgundischen Niederlanden im 15. Jahrhundert, Wirtschafts-, Sozial- und Umweltgeschichte, 5, Schwabe, Basel, 2015 (in German).

Camenisch, C., Keller, K., and Salvisberg, M.: The Coldest Decade of the Millennium?, The Spörer Minimum, the Climate during the 1430s, and its Economic, Social and Cultural Impact, 04 December 2014-05 December 2014 Bern, in: H-Soz-Kult, 11 July 2014, http://www.hsozkult.de/event/id/termine-25424 (08 June 2015), 2015.

Cardauns, H., Hegel, K., Schröder, K. G. T., and Birlinger, A. (Ed.): Chronica van der hilliger stat von Coellen bis 1499, zweite Hälfte, Die Chroniken der niederrheinischen Städte, Cöln, 3, Die Chroniken der Deutschen Städte, 14, S. Hirzel, Leipzig, 1877 (in German).

Chuine, I., Yiou, P., Viovy, N., Seguin, B., Daux, V., and Le Roy Ladurie, E.: Grape ripening as a past climate indicator, Nature, 432, 289-290, 2004.

De Jonghe, J. A. (ed.): Cronijcke van den Lande ende Graefscepe van Vlaenderen van de jaeren 405 tot 1492, 4, Hebbelynck, Rotterdam, 1840 (in Dutch).

De Kraker, A. M. J.: Reconstruction of storm frequency in the North Sea Area of the Preindustrial Period, 1400-1625 and the connection with reconstructed time series of temperatures, History Meteorol., 2, 51-69, 2005.

De Kraker, A. M. J.: Storminess in the Low Countries, 1390-1725, Environ. History, 19, 149-171, 2013.

De Voogd, C.: Histoire des Pays-Bas, Des origines à nos jours, Fayard, Paris, 2003 (in French).

Dobrovolný, P., Moberg, A., Brázdil, R. Pfister, C., Glaser, R., Wilson, R., van Engelen, A., Limanówka, D., Kiss, A., Halíčková, M., Macková, J., Riemann, D., Luterbacher, J., and Böhm, R.: Monthly, seasonal and annual temperature reconstructions for Central Europe derived from documentary evidence and instrumental records since AD 1500, Climatic Change, 101, 69-107, 2010. 
Dobrovolný, P., Brázdil, R., Trnka, M., Kotyza, O., and Valášek, H.: Precipitation reconstruction for the Czech Lands, AD 15012010, Int. J. Climatol., 35, 1-14, 2014.

Dussart, H. (Ed.): Fragments inédits de Romboudt de Doppere, Chronique brugeoise de 1491 à 1498, De Plancke, Bruges, 1892 (in Latin).

Easton, C.: Les hivers dans l'Europe occidentale, Étude statistique et historique sur leur température, Discussion des observations thermométriques 1852-1916 et 1757-1851, tableaux comparatifs, classification des hivers 1205-1916, notices historiques sur les hivers remarquables, bibliographie, E. J. Brill, Leiden, 1928 (in French).

Erbe, M.: Belgien, Niederlande, Luxemburg, Geschichte des niederländischen Raumes, Kohlhammer, Stuttgart, 1993 (in German).

Fris, V. (Ed.): Dagboek van Ghent van 1447 tot 1470 met een vervolg van 1477 tot 1515 , 2, Maatschappij der Vlaamsche Bibliophilen, 4. Serie, 12, C. Annoot-Braeckman, Gent, 1904 (in Dutch).

Geary, P.: Chronicles, annals, and other forms of memoria, in: Chronicon, Medieval narrative sources, A chronological guide with introductory essays, editted by: Bak, J. M. and Jurković, I., Brepols essays in European culture, 5, Brepols, Turnhout, Belgium, 13-23, 2013.

Glaser, R.: Klimageschichte Mitteleuropas, 1200 Jahre Wetter, Klima, Katastrophen: Mit Prognosen für das 21. Jahrhundert, 3rd Edn., Primus, Darmstadt, 2013 (in German).

Glaser, R. and Riemann, D.: A thousand-year record of temperature variations for Germany and Central Europe based on documentary data, J. Quaternary Sci., 24, 5, 437-449, 2009

Gottschalk, M. K. E.: Stormvloeden en rivieroverstromingen in Nederland - Storm surges and river floods in the Netherlands, 2 (De periode 1400-1600 - the periode 1400-1600), Van Gorcum, Assen, Netherlands, 1975 (in Dutch).

Grotefend, H.: Taschenbuch der Zeitrechnung des deutschen Mittelalters und der Neuzeit, 13th Edn., Hahnsche Buchhandlung, Hannover, 1991 (in German).

Hennig, R.: Katalog bemerkenswerter Witterungsereignisse von den ältesten Zeiten bis zum Jahre 1800, Abhandlungen des Königlichen Preussischen Meteorologischen Instituts, 2, 4, A, Asher \& Co., Berlin, 1904 (in German).

Hoffmann, R. C.: An environmental history of Medieval Europe, Cambridge Medieval Textbooks, Cambridge University Press, Cambridge, 2014.

Ingram, M. J., Underhill, D. J., and Farmer, G.: The use of documentary sources for the study of past climates, in: Climate and history. Studies in past climates and their impact on man, edited by: Wigley, T. M. L., Ingram, M. J., and Farmer, G., Cambridge University Press, Cambridge, 180-213, 1981.

Jappe Alberts, W. (Ed.): De Stadsrekeningen van Arnhem, 1 (13531377), J. B. Wolters, Groningen, 1967 (in Dutch).

Jappe Alberts, W. (Ed.): De Stadsrekeningen van Arnhem, 2 (13771401), Wolters-Noordhoff, Groningen, 1969 (in Dutch).

Jappe Alberts, W. (Ed.): De Stadsrekeningen van Arnhem, 3 (14021420), Wolters-Noordhoff, Groningen, 1971 (in Dutch).

Jappe Alberts, W. (Ed.): De Stadsrekeningen van Arnhem, 4 (14201427), Wolters-Noordhoff, Groningen, 1978 (in Dutch).

Jappe Alberts, W. (Ed.): De Stadsrekeningen van Arnhem, 5 (14281432), Gemeentearchief Arnhem, Arnhem, 1985 (in Dutch).
Kervyn de Lettenhove, J. M. B. C. (Ed.): Chronique de Jean Brandon avec les additions d'Adrien de But, in: Chroniques des religieux des Dunes, Jean Brandon - Gilles de Roye, Adrien de Brut, Chroniques realtives à l'histoire de la Belgique sous la domination des ducs de Bourgogne, vol. 1, Publications de la Commission royale d'histoire, Collection de chroniques belges inédites et de documents inédits relatifs à l'histoire de la Belgique 12, Imprimerie de Hayez, Brussels, 1-166, 1870 (in Latin).

Kington, J.: Climate and weather, The New Naturalist Library, 115, Collins, HarperCollins, London, 2010.

Kiss, A.: Floods and weather in 1342 and 1343 in the Carpathian Basin, J. Environ. Geogr., 2, 37-47, 2009.

Kronk, G.: A catalog of comets, 1 (Ancient-1799), Cambridge University Press, Cambridge, 1999.

Kuys, J., de Leeuw, L., Paquay, V., and van Schaïk, R. (Ed.): De Tielse kroniek. Een geschiedenis van de Lage Landen van de Volksverhuizingen tot het midden van de vijftiende eeuw, met een vervolg over de jaren 1552-1566, Uitgeverij Verloren, Amsterdam, 1983 (in Dutch).

Lamb, H. H.: Climate, Present, past and future, 2 (Climatic history and the future), Methuen \& Co. Ltd, London, 1977.

Lamb, H. H.: Climate, history and the Modern world, Methuen \& Co. Ltd, London, 1982.

Lambert, V.: Chronicles of Flanders 1200-1500. Chronicles written independently from "Flandria Generosa", Verhandelingen der Maatschappji voor Geschiedenis en Oudenheitkunde, 19, Maatschappij voor Geschiedenis en Oudheidkunde te Gent, Gent, 1993.

Lamprecht, K.; Franck, J.; Nörrenberg, C.; Ulrich, A.; Jostes, F., and Ilgen, T. (Ed.): Die Duisburger Chronik des Johann Wassenberch von 1474-1517, Die Chroniken der westfälischen und niederrheinischen Städte. Soest und Duisburg, 3, Die Chroniken der Deutschen Städte, 20, S. Hirzel, Leipzig, 177-261, 1895 (in German).

Le Roy Ladurie, E.: Times of feast, times of famine. A history of climate since the Year 1000, Allen \& Unwin, London (Original: Histoire du climat depuis l'an mil, Flammarion, Paris, 1967), 1972.

Le Roy Ladurie, E.: Canicules et glaciers (XIIIe-XVIIIe siècles), Histoire humaine et comparée du climat, 1, Fayard, Paris, 2004 (in French).

Litzenburger, L.: Une ville face au climat: Metz à la fin du Moyen Âge. 1400-1530, PUN - Editions Universitaires de Lorraine, Nancy, 2015 (in French).

Mauelshagen, F. : Klimageschichte der Neuzeit, 1500-1900, Wissenschaftliche Buchgesellschaft, Darmstadt, 2010 (in German).

Ogilvie, A. and Farmer, G.: Documenting the Medieval climate, in: Climates of the British Isles. Present, past, future, edited by: Hulme, M. and Barrow, E., Routledge, London, New York, 112133, 1997.

Pfister, C.: Das Klima der Schweiz von 1525-1860 und seine Bedeutung in der Geschichte von Bevölkerung und Landwirtschaft, Vol. 1: Klimageschichte der Schweiz, 1525-1860, Academica helvetica, 6, Haupt, Bern, 1984 (in German).

Pfister, C.: Une rétrospective météorologique de l'Europe. Un système de reconstitution de l'évolution du temps et du climat en Europe depuis le Moyen Âge central, Histoire \& Mesure, 3, 313 358, 1988 (in French). 
Pfister, C.: Wetternachhersage, 500 Jahre Klimavariationen und Naturkatastrophen, Paul Haupt, Bern, 1999 (in German).

Pfister, C.: Balancing between reconstructing past climate and human dimension of destructive weather, The crux and challenge of historical climatology, in: An environmental history of the Early Modern Period. Experiments and perspectives, edited by: Knoll, M. and Reith, R., LIT Verlag, Vienna, 5-10, 2014.

Pfister, C. and Brázdil, R.: Climatic variability in sixteenth-century Europe and its social dimension. A synthesis, Climatic Change, 43, 5-53, 1999.

Pfister, C., Brázdil, R., Glaser, R., Barriendos, M., Camuffo, D., Deutsch, M., Dobrovolný, P., Enzi, S., Guidoboni, E., Kotyza, O., Militzer, S., Racz, L., and Rodrigo, F. S.: Documentary evidence on climate in the sixteenth century Europe, Climatic Change, 43, 55-110, 1999.

Pfister, C., Luterbacher, J., Wanner, H., Wheeler, D., Brázdil, R., Ge, Q., Hao, Z., Moberg, A., Grab, S., and del Prieto, M.: Documentary Evidence as Climate Proxie. Proxy-specific white paper produced from the PAGES/CLIVAR workshop, Trieste, June 2008, in: PAGES (Past Global Changes), Bern 2009.

Prevenier, W. and Blockmans, W. P.: The Burgundian Netherlands, Cambridge University Press, Cambridge, 1986.

Pribyl, K., Cornes, R. C., and Pfister, C.: Reconstructing medieval April-July mean temperatures in East Anglia, 1256-1431, Climatic Change, 113, 393-412, 2012.

Reuss, M.: Introduction to the special issue on water, management, communities, and environment, Jaarboek voor Ecologische Geschiedenis, 10, 1-7, 2005/06.

Rohr, C.: Extreme Naturereignisse im Ostalpenraum. Naturerfahrung im Spätmittelalter und am Beginn der Neuzeit, Umwelthistorische Forschungen, 4, Böhlau, Köln, 2007 (in German).

Rohr, C.: Macht der Sterne, Allmacht Gottes oder Laune der Natur? Astrologische Expertendiskurse über Krisen und Naturrisiken im späten Mittelalter und am Beginn der Neuzeit, in: Krisengeschichte(n), "Krise" als Leitbegriff und Erzählmuster in kulturwissenschaftlicher Perspektive, edited by: Meyer, C., PatzelMattern, K., Schenk, G. J., Vierteljahrschrift für Sozial- und Wirtschaftsgeschichte, Beihefte, 210, Stuttgart, 361-385, 2013 (in German).

Schmid, R.: Geschichte im Dienst der Stadt, Amtliche Historie und Politik im Spätmittelalter, Chronos, Zürich, 2009 (in German).

Schmid, R.: Town chronicles, Encyclopedia of the Medieval chronicle, ed. by Dunphy, G., Brill, Leiden, vol. 2, 1432-1438, 2012.

Schnerb, B.: L'État bourguignon 1363-1477, Perrin, Paris, 1999 (in French).

Schroeter, J. F. W.: Sonnenfinsternisse von 600 bis 1800 n. Chr. Spezieller Kanon der zentralen Sonnen- und Mondfinsternisse, welche innerhalb des Zeitraumes von 600 bis 1800 n. Chr. in Europa sichtbar waren, Jacob Dybwad, Oslo (Kristiania), 1923 (in German).

Schubert, E.: Essen und Trinken im Mittelalter, Primus, Darmstadt, 2006 (in German).
Schwarz-Zanetti, G.: Grundzüge der Klima- und Umweltgeschichte des Hoch- und Spätmittelalters in Mitteleuropa, Ph.D. thesis, University of Zurich, Zurich, 1998 (in German).

Shabalova, M. V. and van Engelen, A. F. V.: Evaluation of a reconstruction of winter and summer temperatures in the Low Countries, AD 764-1998, Climatic Change, 58, 219-242, 2003.

Tuetey, A. (Ed.): Journal de Clément de Fauquembergue, greffier du parlement de Paris, 1417-1435, vol. 1, Librairie Renouard, Paris 1903 (in French).

Van Bavel, B.: Manors and markets. Economy and society in the Low Countries 500-1600, Oxford University Press, Oxford, 2010.

van Caenegem, R. C.: Introduction aux sources de l'histoire médiéval. Typologie, histoire de l'érudition médiévale, grandes collections, sciences auxiliaires, bibliographie, Brepols, Turnhout, Belgium, 1997 (in French).

Vanderlinden, É.: Chronique des événements météorologiques en Belgique jusqu'en 1834, L'Académie Royale de Belgique, Deuxième série, 6, Maurice Lamertin, Brussels, 1924 (in French).

Van Engelen, A. F. V., Buisman, J., and IJnsen, F.: A millennium of weather, winds and water in the Low Countries, in: History and climate: Memories of the future?, ed. by Jones, P. D., Ogilvie, A. E. J., Davies, T. D., and Briffa, K. R., Kluwer Academic, New York, 101-123, 2001.

Wegmann, M.: Naturwahrnehmung im Mittelalter im Spiegel der lateinischen Historiographie des 12. und 13. Jahrhunderts, Lateinische Sprache und Literatur des Mittelalters, 40, Peter Lang, Bern, 2005 (in German).

Weikinn, C.: Quellentexte zur Witterungsgeschichte Europas von der Zeitwende bis zum Jahr 1850, Hydrographie 1: Zeitwende1500, Quellensammlung zur Hydrographie und Meteorologie, 1, Borntraeger, Berlin, 1958 (in German).

Wetter, O. and Pfister, C.: Spring-summer temperatures reconstructed for northern Switzerland and southwestern Germany from winter rye harvest dates, 1454-1970, Clim. Past., 7, 13071326, doi:10.5194/cp-7-1307-2011, 2011.

Wetter, O., Pfister, C., Weingartner, R., Luterbacher, J., Reist, T., and Trösch, J.: The largest floods in the high Rhine Basin since 1268 assessed from documentary and instrumental evidence, Hydrolog. Sci. J., 56, 733-758, 2011.

Wetter, O., Pfister, C., Werner, J. P., Zorita, E., Wagner, S., Seneviratne, S. I., Herget, J. Grünewald, U., Luterbacher, J., Alcoforado, M.-J., Barriendos, M., Bieber, U., Brázdil, R., Burmeister, K. H., Camenisch, C., Contino, A., Dobrovolný, P., Glaser, R., Himmelsbach, I., Kiss, A., Kotyza, O., Labbé, T., Limanówka, D., Litzenburger, L., Nordli, Pribyl, K., Retsö, D., Riemann, D., Rohr, C., Siegfried, W., Söderberg, J., and Spring, J.-L.: The year-long unprecedented European heat and drought of 1540 - a worst case, Climatic Change, 125, 349-363, 2014. 